\title{
KARAKTERISTIK PROGRAM PEMBERDAYAAN MUSTAHIK OLEH LEMBAGA AMIL ZAKAT NASIONAL DI INDONESIA
}

\author{
Ernawati \\ Universitas Halu Oleo Kendari \\ ernakarim@gmail.com
}

\begin{abstract}
This study aims to investigate the characteristics of empowerment mustabik by Lembaga Amil Zakat Nasional (LAZNAS). The sample consisted of 13 LAZNAS. Data obtained through the publication of directories on line LAZNAS. Characteristics of the empowerment program assessed in six dimensions: type of aid, the target group, target area, target age, gender and agriculture-based. The data were analyzed descriptively with tabulation, percentages and charts. The results showed that the type of the empowerment program conducted by LAZNAS in Indonesia consists of: financial aid, assistance tools, training and mentoring, as well as other type such as reinforcement, the legality of operations and strengthening the network of business. However, not all LAZNAS adopt this type of aid. The whole LAZNAS have targeted both mustabik empowering individuals and groups. LAZNAS also generally have a Village Project. On the other hand, LAZNAS in general has given space to the development of community enterprises in the agricultural sector. But lack of attention at a young age and female mustabik. Only three LAZNAS that provides direct attention to the younger group; and one for woman empowerment.
\end{abstract}

Keywords: Empowerment, Economic, Mustahik, Program

\begin{abstract}
Abstrak
Penelitian ini bertujuan untuk mengetabui karakteristik pemberdayaan mustabik oleh LAZNAS. Sampel penelitian terdiri dari 13 LAZNAS. Data diperoleh melalui hasil publikasi direktori on line LAZNAS. Karakteristik program pemberdayaan mustabik dikaji melalui 6 (enam) dimensi: jenis bantuan, kelompok sasaran, wilayah sasaran, usia sasaran, gender dan berbasis pertanian secara umum. Analisis data dilakukan secara deskriptif dengan tabulasi, persentase dan grafik. Hasil penelitian menunjukkan bahwa bentuk program pemberdayaan yang dilakukan oleh LAZNAS terdiri dari: bantuan modal, bantuan sarana, pelatihan dan pendampingan, penguatan produk, legalitas usaha dan penguatan jaringan. Namun tidak seluruh LAZNAS mengadopsi jenis bantuan tersebut. Selurub LAZNAS memiliki target pemberdayaan baik mustabik perorangan maupun kelompok. LAZNAS secara umum memiliki desa binaan, dan fokus pada program berbasis desa/kampung, dan memberi ruang bagi berkembangnya usaha masyarakat pada sektor pertanian. Namun masih minim memberikan perhatian pada mustabik usia muda dan perempuan. Hanya 3 LAZNAS yang memberikan perbatian langsung terbadap kelompok usia muda; dan hanya 1 yang memberikan perhatian langsung sebagai program utama pada kelompok perempuan.
\end{abstract}

Kata Kunci: Pemberdayaan, Ekonomi, Mustahik, Program

Permalink/DOI: http://dx.doi.org/10.18326/infsl3.v10i2.309-334 


\section{Pendahuluan}

Zakat sebagai rukun Islam ke-empat yang bermakna kewajiban seorang muslim yang memiliki pendapatan/harta yang telah mencapai nisab (batasan minimal harta yang wajib dizakati) dan haul (kepemilikan satu tahun penuh). Dengan kadar zakat 2,5 persen (kecuali untuk zakat pertanian) maka dapat diestimasi bahwa potensi zakat akan berkisar 2,5 persen dari produk domestik bruto (PDB). Namun dapat lebih tinggi maupun lebih rendah dengan memasukkan unsur tabungan dan rumah tangga, serta mempertimbangan syarat wajib zakat, seperti kepemilikan produksi di tangan muslim dan kehalalan produk. Hasil penelitian Firdaus dkk (2012:33) menunjukkan bahwa potensi zakat di Indonesia sekitar 217 triliun rupiah atau setara dengan 3,40 persen dari Produk Domestik Bruto (PDB) tahun 2010, yang dirinci sebagaimana Tabel 1. Potensi terbesar zakat bersumber dari sektor industri, kemudian sektor rumah tangga. Adapun potensi zakat tabungan sekitar 17 triliun rupiah.

\section{Tabel 1}

\section{Potensi Zakat Indonesia}

\begin{tabular}{cl}
\multicolumn{1}{c}{ Jenis Zakat Harta } & \multicolumn{1}{c}{$\begin{array}{c}\text { Potensi } \\
\text { (Triliun Rp) }\end{array}$} \\
\hline $\begin{array}{c}\text { Rumah Tangga } \\
\text { Industri } \\
\text { Perusahaan Pemerintah }\end{array}$ & 82,79 \\
Perusahaan Swasta & 2,40 \\
Total Industri & 114,89 \\
Tabungan & 117,29 \\
Bank Pemerintah & 16,10 \\
Bank Syariah & 0,89 \\
Total Tabungan & 16,99 \\
\hline
\end{tabular}

Sumber: Firdaus, dkk (2012) diringkas hal 21-33 
Kekuatan organisasi pengelola zakat ternyata belum mampu mengoptimalkan penerimaan zakat, yang hanya mencapai 1 persen dari potensi yang ada. Organisasi pengelola zakat di Indonesia sebanyak 38.013 organisasi yang terdiri dari Badan Amil Zakat Nasional (BAZNAS) 1 unit, Lembaga Amil Zakat Nasional (LAZNAS) 18 unit, Lembaga Amil Zakat (LAZ) propinsi/kabupaten 47 unit, unit pengumpul zakat (UPZ) 8.680 unit, dan sisanya adalah Badan Amil Zakat Daerah (BAZDA) baik yang berkedudukan di tingkat propinsi, kabupaten, kecamatan, maupun kelurahan (Juwaini, 2011: 33-41).

Rendahnya zakat coverage merupakan pekerjaan rumah baik pemerintah maupun organisasi pengelola zakat. Pekerjaan rumah tersebut tidak hanya sampai disini namun juga terkait dengan pendistribusian zakat, untuk kemaslahatan ummat. Pada aspek ekonomi misalnya, zakat dapat menjadi salah satu instrumen pemberdayaan masyarakat dan pengentasan kemiskinan. Untuk tujuan ini, zakat dapat dikelola secara produktif. Peraturan Menteri Agama No 52 tahun 2014 telah menyiratkan kebolehan mendayagunakan dana zakat untuk usaha produktif sengan syarat sebagaimana pasal 33: (a) apabila kebutuhan dasar mustahik telah terpenuhi; (b) memenuhi ketentuan syariah; (c) menghasilkan nilai tambah ekonomi untuk mustahik; dan (d) mustahik berdomisili di wilayah kerja lembaga pengelola zakat. Selanjutnya pada pasal 34 dinyatakan bahwa pendayagunaan zakat untuk usaha produktif dapat dilakukan paling sedikit memenuhi ketentuan: (a) penerima manfaat merupakan perorangan atau kelompok yang memenuhi ketentuan mustahik; dan (b) mendapat pemdampingan LAZ diwilayah domisili mustahik.

Pada sisi lain, hendaknya pemberdayaan ekonomi zakat tidak hanya sampai menghasilkan nilai tambah untuk mustahik sebagaimana peraturan terebut di atas, namun lebih jauh lagi dapat merubah kondisi mustahik menjadi muzakki. Studi ini mengkaji berbagai bentuk (karakteristik) program dan capaian pemberdayaan ekonomi yang dilakukan oleh organisasi pengelola zakat skala nasional Lembaga Amil Zakat Nasional (LAZNAS). Bagaian kedua dari tulisan ini menyajikan kajian literatur, bagian ketiga metode penelitian, selanjutnya hasil dan pembahasan, dan terakhir kesimpulan. 


\section{Konsep Zakat, Infak dan Sedekah}

Zakat, infaq, sedekah dan wakaf memiliki persamaan makna sebagai pengeluaran seorang muslim untuk kebaikan di jalan Allah. Namun keempat jenis pengeluaran ini memiliki perbedaan dari aspek syariat. Zakat adalah harta yang wajib dikeluarkan oleh seorang muslim atau badan usaha yang dimiliki oleh orang Islam untuk diberikan kepada yang berhak menerimanya sesuai dengan syarat-syarat tertentu yang telah disyariatkan. Jika zakat ada nisab (batasan minimal harta yang wajib dizakati) dan takarannya, maka infak dan sedekah tidak mengenal nisab dan takaran. Zakat harus diberikan pada mustahik tertentu (8 asnaf), maka infak boleh diberikan kepada siapapun. Sementara sedekah maknanya lebih luas dari zakat dan infak. Sedekah dapat bermakna infak, zakat dan kebaikan non-materi lainnya. Adapun pengertian wakaf yaitu harta yang dipisahkan dari kepemilikan seseorang untuk dimanfaatkan selamanya dan atau jangka waktu tertentu guna keperluan ibadah dan/atau kesejahteraan umum menurut syariah.

Syarat umum harta yang wajib dizakati yaitu: kepemilikan sempurna, berkembang (produktif atau berpotensi produktif), mencapai nisab, melebihi kebutuhan pokok, terbebas dari hutang, serta telah dimiliki selama satu tahun penuh (Yasin, 2011: 15-18). Pada Peraturan Menteri Agama No. 52 Tahun 2014 dinyatakan bahwa zakat harta terdiri dari: (1) zakat emas, perak dan logam mulia lainnya; (2) zakat uang dan surat berharga lainnya; (3) zakat perniagaan; (4) zakat pertanian, perkebunan dan kehutanan; (5) zakat peternakan dan perikanan; (6) zakat pertambangan; (7) zakat perindustrian; (8) zakat pendapatan dan jasa; dan (9) zakat rikaz (harta temuan).

Adapun nisab dan kadar zakat dari berbagai jenis harta yang dikenakan zakat disajikan sebagaimana Tabel 2 yang menunjukkan bahwa secara umum nisab zakat distandarkan dengan 85 gr emas; kecuali hasil pertanian, perusahaan jasa dan barang temuan. Barang temuan tidak memiliki nisab dan wajib dikeluarkan sebesar seperlima atau 20 persen dari nilai harta. Pada sisi lain, zakat ternak yang wajib dizakati terbagi menjadi 2 kelompok, yaitu: yang dipelihara dalam kandang; dan ternak hasil pengembalaan. Ternak 
yang dipelihara dalam kandang dianalogkan dengan perniagaan sehingga nisab dan kadar zakatnya sama dengan perniagaan. Sementara ternak hasil pengembalaan yang wajib dikeluarkan zakatnya jika binatang ternak digembalakan di tempat-tempat umum dan tidak dimanfaatkan untuk kepentingan alat produksi (pembajak sawah), mencapai nisab (batasan minimal harta yang wajib dikeluarkan zakat). Nisab untuk unta adalah 5 (lima) ekor, sapi 30 ekor, kambing atau domba 40 ekor dengan ketentuan volume zakatnya sudah ditentukan sesuai karakteristik tertentu dan diambil dari binatang ternak itu sendiri.

Tabel 2

Nisab dan Kadar Zakat Berdasarkan Jenis Harta

\begin{tabular}{lll}
\hline \multicolumn{1}{c}{ Jenis harta } & \multicolumn{1}{c}{ Nisab } & \multicolumn{1}{c}{ Kadar zakat (\%) } \\
\hline Emas & 85 gr & 2,5 \\
Perak & 595 gr perak & 2,5 \\
Logam mulia & 85 gr emas & 2,5 \\
Uang dan surat berharga & 85 gr emas & 2,5 \\
Perniagaan & 85 gr emas & 2,5 \\
& & 10 untuk tadah hujan \\
Hasil Pertanian & 653 kg gabah & dan 5 untuk jenis \\
& & lainnya \\
Ternak dipelihara dalam & 85 gr emas & 2,5 \\
kandang & 85 gr emas & 2,5 \\
Perikanan & 85 gr emas & 2,5 \\
Pertambangan & 653 kg gabah & 2,5 \\
Perusahaan bidang jasa & 0 & $20 \%$ \\
Barang Temuan & &
\end{tabular}

Sumber: Peraturan Menteri Agama No 52 tahun 2014, diringkas 


\section{Pemberdayaan Ekonomi Zakat}

Pemberdayaan adalah mencakup upaya-upaya untuk mengembangkan daya dan potensi yang dimiliki oleh masyarakat, melindungi masyarakat yang lemah, menguatkan kelembagaan keuangan dan pembangunan yang dikelola oleh masyarakat dan meningkatkan derajat kemandirian di masyarakat. dan masyarakat dipandang sudah berdaya dan mencapai tingkat kemandirian bilamana masyarakat tersebut sudah mampu memanfaatkan akses pada sumberdaya capital atau pada lembaga-lembaga keuangan formal lainnya. (Triwibowo dan Subono, 2009: 59)

Suharto (2005: 67) mengemukakan bahwa pelaksanaan proses dan pencapaian melalui pendekatan pemberdayaan yang dapat di singkat menjadi 5P, yaitu: 1) pemungkinan: menciptakan suasana atau iklim yang memungkinkan potensi masyarakat berkembang secara optimal; 2) penguatan, yaitu memperkuat pengetahuan dan kemampuan yang dimiliki masyarakat dalam memecahkan masalah dan memenuhi kebutuhan-kebutuhannya; 3) perlindungan, yaitu melindungi masyarakat terutama masyarakat yang lemah agar tidak tertindas oleh masyarakat yang kuat dengan tujuan menjaga persaingan yang tidak seimbang apalagi tidak sehat antara yang kuat dan yang lemah dan mencegahnya eksploitasi kelompok kuat kepada kelompok lemah; 4) penyokongan yaitu memberikan bimbingan dan dukungan agar masyarakat mampu menjalankan peranan dan tugas-tugas kehidupannya; dan 5) pemeliharaan, yaitu memelihara kondisi yang kondusif agar tetap terjadi keseimbangan hak kekuasaan antara berbagai kelompok dalam masyarakat.

Zakat juga dapat didayagunakan sebagai zakat produktif. Pendayagunaan zakat produktif juga sebagai salah satu instrumen pengentasan kemiskinan. Tujuan zakat tidak sekedar menyantuni orang miskin secara konsumtif, tetapi mempunyai tujuan yang lebih permanen yaitu mengentaskan kemiskinan (Qadir, 2001: 83). Pendayagunaan zakat secara produktif pernah dicontohkan oleh Khalifah Umar Ibn Khathab yang menyerahkan zakat berupa tiga ekor unta kepada salah seorang mustahik yang rutin menerima zakat tetapi nasibnya belum berubah. Pada saat penyerahan tiga ekor unta tersebut, khalifah mengharapkan agar yang bersangkutan tidak datang lagi sebagai 
penerima zakat namun sebagai pembayar zakat. Harapan Khalifah Umar Ibn Khathab menjadi kenyataan, pada tahun berikutnya mustahik tersebut datang kepada Khalifah Umar Ibn Khathab bukan meminta zakat, tetapi untuk menyerahkan zakatnya (Ra'ana, 1978: 88).

Bariadi (2005: 25) mengemukakan 2 bentuk alokasi dana zakat, yaitu: bentuk sesaat dan bentuk pemberdayaan. Pada bentuk sesaat, zakat hanya diberikan kepada mustahik tanpa disertai target terjadinya kemandirian ekonomi dalam diri mustahik. Bentuk ini di terapkan dikarenakan mustahik yang barsangkutan tidak mungkin lagi mandiri, seperti pada orang tua yang sudah jumpo atau mustahik cacat. Selanjutnya alokasi zakat dalam bentuk pemberdayaan, merupakan penyaluran zakat yang disertai target merubah keadaan penerima dari kondisi kategori mustahik menjadi kategori muzakki, yang tentunya disertai dengan berbagai program pendayagunaan zakat dalam mendorong motivasi mustahik untuk berubah.

Ali (1988: 63) menyajikan beberapa bentuk pendayagunaan untuk pemberdayaan mustahik: (a). Pendayagunaan dalam bentuk pemberian bantuan uang sebagai modal kerja usaha mikro dalam meningkatkan kapasitas dan mutu produksi usahanya; (b) pendayagunaan yang kreatif, maksudnya penyaluran dalam bentuk alat-alat sekolah dan beasiswa dan lain-lain; (c) dukungan kepada mitra binaan untuk berperan serta dalam berbagai upaya untuk pemberdayaan usaha mikro dan pembangunan sebuah proyek; (d) penyediaan pendamping lapangan untuk menjamin keberlanjutan usaha, misalnya pendampingan usaha yang mengembangkan usaha mikro dalam bentuk alih pengetahuan, keterampilan dan informasi; dan (e) pembangunan industri untuk pemberdayaan yang ditujukan bagi masyarakat mustahik melalui program-program yang bertujuan yakni penciptaan lapangan kerja, peningkatan usaha, pelatihan, pembentukan organisasi.

Pada sisi lain, Ridwan (2005: 122-124) mengemukakan beberapa model sistem pengelolaan zakat produktif, yaitu: a) Surplus Zakat Budget, yaitu pengumpulan dana zakat yang pendistribusiannya hanya di bagikan sebagian dan sebagian lainnya digunakan dalam pembiayaan usaha-usaha produktif dalam bentuk 
zakat certificate. Pada pelaksanaannya, zakat diserahkan oleh muzakki kepada amil yang kemudian dikelola menjadi dua bentuk yaitu bentuk sertifikat dan uang tunai, selanjutnya sertifikat diberikan kepada mustahik dengan persetujuan mustahik. Uang tunai yang terkandung dalam sertifikat tersebut selanjutnya digunakan dalam operasional perusahaan, yang selanjutnya perusahaan yang didanai diharapkan dapat berkembang pesat dan menyerap tenaga kerja dari golongan mustahik sendiri, selain itu perusahaan juga diharapkan dapat memberikan bagi hasil kepada mustahik pemegang sertifikat. Apabila jumlah bagi hasil telah mencapai nishab dan haul nya maka mustahik tersebut dapat berperan menjadi muzakki. b) In kind, yaitu sistem pengelolaan zakat dalam bentuk alat-alat produksi seperti mesin ataupun hewan ternak yang dibutuhkan oleh kaum ekonomi lemah yang memiliki keinginan untuk berusaha atau berproduksi, baik untuk mereka yang baru akan memulai usaha maupun yang ingin mengembangkan usaha yang sudah dijalaninya. c) Revolving fund, yaitu sistem pengelolaan zakat dengan pinjaman dana zakat kepada mustabik dalam bentuk pembiayaan qardrul hasan. Mustahik menggunakan dana pinjaman tersebut untuk usaha agar dapat mengembalikan sebagian atau seluruh dana yang di pinjam tersebut dalam kurun waktu tertentu. Setelah dana tersebut dikembalikan kepada amil kemudian amil menggulirkan dana tersebut pada mustabik lainnya.

Tentunya berbagai program pemberdayaan tersebut diharapkan dapat benar-benar membantu mustahik untuk lebih mandiri. Beberapa studi yang telah dilakukan terkait keberhasilan pemberdayaan mustahik diantaranya penelitian yang dilakukan oleh Febianto and Ashany (2012) menunjukkan bahwa pemberian bantuan modal usaha melalui qardhul hasan yang dikelola oleh LAZ Dompet Duafa Jawa Timur mampu memperbaiki ekonomi penerima bantuan. Penelitian ini sejalan dengan penelitian Noerwenda, and Mulyaningsih (2014). Selanjutnya Nafiah (2015) melakukan penelitian untuk kasus pemberdayaan masyarakat yang dikelola oleh BAZNAS di Kabupaten Gresik menemukan bahwa terdapat pengaruh positif antara pendayagunaan zakat produktif pada program ternak bergulir BAZNAS terhadap kesejahteraan mustahik. Namun hasil penelitian Patmawati sebagimana dikutip 
Ibrahim dan Ghazali (2014: 123) menunjukkan kurang berhasilnya pengelolaan zakat dalam bentuk pembiayaan mikro, dengan tingkat keberhasilan kurang dari 30 persen.

\section{Metode Penelitian}

Penelitian menggunakan data sekunder hasil publikasi lembaga amil zakat (LAZ). Populasi penelitian merupakan seluruh Lembaga Amil Zakat Nasional (LAZNAS). Sampel diambil merupakan LAZNAS yang diakui pemerintah sebagai pengurang pendapatan kena pajak (PKP) berdasarkan Peraturan Direktur Jenderal Pajak Nomor PER33/PJ/2011 dan tidak berafiliasi dengan perbankan konvensional atau sebanyak 17 LAZNAS. Namun berdasarkan ketersediaan data maka jumlah sampel yang diolah lebih lanjut yaitu 13 LAZNAS, yang disajikan sebagaimana Tabel 3. Data yang dikumpulkan berupa: karakteristik program pemberdayaan, laporan keuangan dan sistem jaringan pengumpulan ZIS. Karakteristik program pemberdayaan mustahik dikaji melalui 6 (enam) dimensi: (1) jenis bantuan: modal, sarana, pelatihan, pendampingan, dan lainnya; (2) kelompok sasaran: perorangan dan atau kelompok/lembaga; (3) wilayah sasaran: kampung/desa dan atau tidak ditentukan; dan (4) usia sasaran: muda atau tidak ditentukan; (5) gender: memiliki program khusus perempuan dan atau tidak ditentukan; dan (6) berbasis pertanian secara umum (termasuk peternakan dan perikanan) dan atau tidak ditentukan. Pengkajian karakteristik didasarkan pada pengungkapan informasi yang disajikan pada masing-masing direktori on line LAZNAS. Analisis data dilakukan secara deskriptif dengan bantuan tabulasi, persentase dan grafik.

\section{Tabel 3}

Sampel Penelitian

\begin{tabular}{llllll}
\hline No & Nama Lembaga Amil Zakat & No & \multicolumn{2}{c}{$\begin{array}{c}\text { Nama Lembaga Amil } \\
\text { Zakat }\end{array}$} \\
\hline 1 & $\begin{array}{l}\text { Badan Amil } \\
\text { (BAZNAS) }\end{array}$ & Zakat Nasional & 8 & $\begin{array}{l}\text { LAZ Pusat Zakat Ummat } \\
\text { Persatuan Islam }\end{array}$ &
\end{tabular}




$\begin{array}{llll}2 & \text { LAZ Dompet Dhuafa Republika } 9 & \begin{array}{l}\text { LAZ Yayasan Bangun } \\ \text { Sejahtera Mitra Umat }\end{array} \\ 3 & \text { LAZ Pos Keadilan Peduli Umat } 10 & \begin{array}{l}\text { LAZ Dompet Peduli Umat } \\ \text { Daarut Tauhid (DUDT) }\end{array} \\ 4 & \begin{array}{l}\text { LAZ Yayasan Baitulmaal } \\ \text { Muamalat }\end{array} & 11 & \begin{array}{l}\text { LAZ Yayasan Rumah Zakat } \\ \text { Indonesia }\end{array} \\ 5 & \begin{array}{l}\text { LAZ Yayasan Dana Sosial Al } \\ \text { Falah }\end{array} \\ 6 & \text { LAZ Baitul Maal Hidayatullah } & 13 & \begin{array}{l}\text { LAZIS Muhammadiyah } \\ \text { LAZIS Nahdlatul Ulama } \\ \text { (LAZIS NU) }\end{array} \\ 7 & \begin{array}{l}\text { LAZ Dewan Da'wah Islamiyah } \\ \text { Indonesia }\end{array} & \end{array}$

\section{Analisis}

Karakteristik Program Pemberdayaan Masyarakat LAZNAS

Lembaga pengelola zakat di Indonesia terdiri dari lembaga yang didirikan oleh pemerintah dan lembaga yang didirikan oleh masyarakat. Lembaga yang didirikan oleh pemerintah yang bertindak sebagai pengumpul zakat yaitu Badan Amil Zakat Nasional dan Daerah (BAZNAS dan BAZDA). Cakupan kerja BAZNAS secara nasional sementara BAZDA hanya berada pada wilayah propinsi maupun kabupaten/kota yang dibentuk oleh pemerintah daerah. Unit pengumpul zakat (UPZ) BAZNAS telah mencapai 101 unit, dan 32 diantaranya merupakan korporat, baik BUMN/BUMD maupun privat.

LAZNAS tampaknya memiliki kekuatan yang cukup besar dari aspek jaringan. LAZNAS PKPU, Rumah Zakat, LAZISNU, PZU merupakan LAZNAS dengan jaringan terbesar. Belum termasuk LAZ Muhammadiyah yang memiliki cabang hingga ke kecamatan di berbagai daerah. Jaringan ini merupakan suatu upaya untuk menjangkau muzakki potensial. Jejaring ini diperkuat oleh sistem pembayaran dana yang lebih mudah berbasis elektronik atau e-banking yang dipadukan dengan sitem manual pembayaran di konter bank, konter lembaga, maupun sistem jemput.

Lembaga amil zakat tampaknya tidak hanya terfokus pada donasi ZISWAF namun memperluas donasi untuk dana 
kemanusiaan, CSR, bahkan dalam bentuk barang. Secara umum, penyaluran dana LAZ diarahkan pada bidang ekonomi, kesehatan, pendidikan, dakwah, dan sosial kemanusiaan. Program sosial kemanusiaan dapat berbentuk tanggap darurat (bencana alam, daerah konflik, dst). Adapun bantuan kesehatan yang dilakukan LAZ diarahkan pada bantuan pengobatan dan penyediaan sarana/ prasarana kesehatan. Sementara dana pendidikan berbentuk beasiswa, pelatihan pendidik, maupun sarana dan prasarana sekolah. Beberapa program dakwah yang dilakukan LAZ yaitu pelatihan dai serta pengadaan sarana dan prasarana ibadah. Sementara alokasi anggaran dalam bidang ekonomi secara umum dalam bentuk bantuan modal, pendampingan usaha, dana bergulir dan peningkatan skill kewirausahaan.

Program pemberdayaan ekonomi mustahik oleh LAZNAS tampaknya memiliki banyak varian sebagaimanaa disajikan pada Tabel 5. Varian terbanyak dimiliki oleh LAZNAS Baitul Maal Muamalat. Meskipun LAZNAS lain hanya memiliki sedikit program pemberdayaan namun dari aspek turunannya juga meliputi beberapa jenis bantuan. Program pemberdayaan LAZNAS Rumah Zakat dalam bentuk bantuan wirausaha, didalamnya mencakup 8 (delapan) sub program yaitu: pelatihan keterampilan, pemberian sarana usaha, pemberian modal, pendampingan bisnis, pendampingan GMP (Good Manufacturing Practices), penguatan produk dan legalitas usaha.

\section{Tabel 5 \\ Bentuk Program Pemberdayaan Beberapa LAZNAS di Indonesia}

\begin{tabular}{ll}
\hline Nama LAZNAS & \multicolumn{1}{c}{ Bentuk Program Pemberdayaan } \\
\hline & - $\begin{array}{l}\text { Bantuan modal dan pendampingan } \\
\text { pedagang }\end{array}$ \\
Pos Keadilan dan & Pendampingan kelompok usaha mandiri \\
Peduli Umat (PKPU) & - $\begin{array}{l}\text { Pasyarakat inkubasi kemandirian } \\
\text { - }\end{array}$ \\
& Program pemberdayaan terhadap \\
& masyarakat pasca bencana \\
\hline
\end{tabular}




\begin{tabular}{|c|c|}
\hline Rumah Zakat（RZ) & $\begin{array}{l}\text { - Bantuan wirausaha } \\
\text { - Pembinaan masyarakat }\end{array}$ \\
\hline Dompet Duafa (DD) & $\begin{array}{l}\text { - Pemberdayaan berbasis peternakan } \\
\text { - Institut Kemandirian } \\
\text { - Pemberdayaan masyarakat berdasarkan } \\
\text { klaster ekonomi } \\
\text { - Pengembangan ekonomi melalui sinergi } \\
\text { BMT Center } \\
\text { - Dana Kepercayaan Sosial untuk masyarakat } \\
\text { miskin }\end{array}$ \\
\hline $\begin{array}{l}\text { Dompet Peduli } \\
\text { Ummat Daruttauhid } \\
\text { (DPU DT) }\end{array}$ & $\begin{array}{l}\text { - Program pemberdayaan ekonomi produktif } \\
\text { yang dikelola secara sistematis, intensif dan } \\
\text { berkesinambungan } \\
\text { - Penggemukan hewan ternak yang } \\
\text { sasarannya adalah memberdayakan } \\
\text { peternak kecil di pedesaan } \\
\text { - Pemberdayaan petani kecil di pedesaan }\end{array}$ \\
\hline $\begin{array}{l}\text { Baitul Maal } \\
\text { Hidayatullah (BMH) }\end{array}$ & $\begin{array}{l}\text { Pengembangan ekonomi MAPAN (Mandiri } \\
\text { Terdepan) melalui pembiayaan qardhul hasan } \\
\text { berbasis pembinaan spiritual }\end{array}$ \\
\hline $\begin{array}{l}\text { Lazis Muhammadiah } \\
\text { (LAZISMU) }\end{array}$ & $\begin{array}{l}\text { - Pendirian dan pengembangan lembaga } \\
\text { keuangan mikro (LKM) yang memiliki } \\
\text { tugas utama memberikan permodalan dan } \\
\text { pendampingan kepada pelaku usaha mikro } \\
\text { - Pengembangan usaha ekonomi berbasis } \\
\text { keluarga } \\
\text { - Pengembangan dan pemberdayaan } \\
\text { - } \text { Pewirausahaan generasi muda } \\
\text { Pemberdayaan petani melalui sistem } \\
\text { pertanian terpadu dan ramah lingkungan. }\end{array}$ \\
\hline LAZIS NU & $\begin{array}{l}\text { Permodalan dan pendampingan usaha bagi } \\
\text { pedagang kaki lima dan usaha rumahan }\end{array}$ \\
\hline
\end{tabular}


Dewan Da'wah Islamiyah Indonesia (DDII)
- Training da'i

- Program pengentasan kemiskinan

- Bantuan peningkatan ekonomi warga

Yayasan Dana Sosial Al Falah (YDSF)

- Bantuan modal usaha Kelompok Usaha Mandiri

- Pelatihan keterampilan usaha dan jejaring bisnis

- Bina ekonomi kecil produktif

- Diklat pelatihan wirausaha

Pusat Zakat Ummat (PZU)

- Peningkatan kesejahteraan di wilayah program bina desa serta ketersediaan hewan ternak (domba atau sapi) bagi program aqiqah dan qurban.

- Pendampingan bagi Koperasi Jasa Keuangan Syariah yang mendapatkan fasilitas pembiayaan mikro dari Bank Muamalat Indonesia Pemberdayaan Kampung Jamur Ciputih Pemberdayaan dan pengembangan Lembaga Keuangan Mikro Syariah Pemberdayaan komunitas usaha mikro

Baitul Maal Muamalat (BMM) Muamalat berbasis masjid Dana bergulir syariah

- Recovery atas perawatan kesehatan, kecelakaan dan kematian kepada para pengusaha mikro

- Linkage program antara Baitulmaal Muamalat dengan Baitul Maal wa Tamwil (BMT) di daerah-daerah kemitraan untuk penghimpunan dana dan penyaluran pembiayaan kepada masyarakat kecil yang membutuhkan. 
- Pemberdayaan potensi masyarakat berbasis tempat tinggal dengan memberikan bantuan bibit tanaman, kandang, hewan ternak dan diklat

Bangun Sejahtera Mitra Umat (BSMU)

Badan Amil Zakat Nasional (BAZNAS)
- Bantuan dana modal usaha bergulir untuk memulai dan mengembangkan kewirausahaan masyarakat menengah kebawah

- Peningkatan keterampilan hidup dan modal usaha untuk para dhuafa usia produktif hingga diharapkan menjadi muzakki baru

- Zakat Community Development (ZCD), yaitu pengembangan komunitas dengan mengintegrasikan aspek sosial (pendidikan, kesehatan, agama, lingkungan, dan aspek sosial lainnya) dan aspek ekonomi secara komprehensif

- Penyaluran ZIS produktif baik melalui pinjaman kebajikan (al qardbul hasan) maupun melalui pembiayaan dengan pola syariah kepada para mustahik, atau lebih dikenal dengan Baitul Qiradh Baznas (BQB)

Sumber: Direktori Online Masing-masing LAZ

Adapun karesteristik program pemberdayaan mustahik yang dilakukan oleh LAZNAS berdasarkan dimensi: jenis bantuan, kelompok sasaran, basis wilayah, kelompok usia, gender, dan basis sub sektor pertaanian/peternakan disajikan sebagaimana Tabel 6. 


\section{Tabel 6}

\section{Karakteristik Program Pemberdayaan Mustahik LAZ} di Indonesia

\begin{tabular}{|c|c|c|c|c|c|c|}
\hline \multirow{2}{*}{$\begin{array}{l}\text { Nama } \\
\text { LAZNAS }\end{array}$} & \multicolumn{6}{|c|}{ Karakteristik Sasaran } \\
\hline & $\begin{array}{l}\text { Jenis } \\
\text { Bantuan }^{1}\end{array}$ & $\begin{array}{l}\text { Kelompok } \\
\text { Sasaran }^{2}\end{array}$ & Wilayah ${ }^{3}$ & Usia $^{4}$ & Gender 5 & Sektor $^{6}$ \\
\hline PKPU & $1,3,4$ & 1,2 & 2 & 2 & 2 & 2 \\
\hline $\mathrm{RZ}$ & $1,2,3,4$ & 1,2 & 1,2 & 2 & 2 & 1,2 \\
\hline DD & $1,2,3,4$ & 1,2 & 1,2 & 1,2 & 2 & 1,2 \\
\hline DPU DT & 1,3 & 1,2 & 1,2 & 2 & 2 & 1,2 \\
\hline $\mathrm{BMH}$ & $1,3,4$ & 1,2 & 2 & 1,2 & 2 & 2 \\
\hline LAZISMU & $1,2,3,4$ & n.a & 1,2 & 1,2 & 1,2 & 1,2 \\
\hline LAZIS NU & $1,2,3,4$ & 1,2 & 2 & 2 & 2 & 2 \\
\hline DDII & $2,3,4$ & 1,2 & 1,2 & 2 & 2 & 1,2 \\
\hline YDSF & 1,3 & 1,2 & 1,2 & 2 & 2 & n.a \\
\hline PZU & $1,2,3$ & 1,2 & 1,2 & 2 & 2 & 1,2 \\
\hline BMM & $1,2,3,4$ & 1,2 & 1,2 & 2 & 2 & 1,2 \\
\hline BSMU & $1,2,3,4$ & n.a & 1,2 & 2 & 2 & 1,2 \\
\hline BAZNAS & n.a & 1,2 & 1,2 & 2 & 2 & 1,2 \\
\hline \multicolumn{7}{|c|}{$\begin{array}{l}\text { }{ }^{1} \text { Jenis bantuan: (1) modal; (2) sarana usaha; (3) pelatihan; (4) } \\
\text { pendampingan. }\end{array}$} \\
\hline \multicolumn{7}{|c|}{${ }^{2}$ Kelompok sasaran: (1) individu; (2) lembaga/kelompok; } \\
\hline \multicolumn{7}{|c|}{${ }^{3}$ Kelompok usia: (1) muda; (2) tidak ditentukan; } \\
\hline \multirow{2}{*}{\multicolumn{7}{|c|}{ "Wilayah sasaran: (1) wilayah kampung/desa; (2) tidak ditentukan; }} \\
\hline & & & & & & \\
\hline${ }^{6}$ Sektor: $(1$ & sertania & secara un & $\mathrm{am} ;(2)$ & lak d & ntukan & \\
\hline
\end{tabular}


Tabel 6 menunjukkan bahwa terdapat minimal 4 jenis bantuan yang diberikan LAZNAS dalam program pemberdayaan mustahik. Namun tidak seluruh LAZNAS mengadopsi jenis bantuan tersebut, khususnya PKPU, DPU DT, BMH, DDII, YDSF dan PSU. Selanjutnya PKPU, BMH dan LAZISNU juga tidak mengungkapkan secara langsung wilayah kampung/desa sebagai sasaran kerja pemberdayaan mustahik. Pada kelompok sasaran usia, hanya 3 dari 13 LAZNAS yang diteliti mengungkap fokus program pemberdayaan bagi generasi muda yaitu: Dompet Duafa, BMH, dan LAZISMU. LAZISMU merupakan satu-satunya LAZNAS yang secara langsung memiliki program utama bidang pemberdayaan perempuan. Sementara dari aspek karakteristik sektor, tampak bahwa PKPU, LAZISNU dan BMH tidak memfokuskan secara langsung pada sektor pertanian secara umum.

\section{Tabel 7}

Proporsi LAZNAS Berdasarkan Dimensi Karakteristik

\begin{tabular}{lll}
\hline \multicolumn{1}{c}{ Dimensi } & Jumlah & $\%$ \\
\hline Jenis Bantuan & 12 & 100,00 \\
Bantuan Modal & 8 & 66,67 \\
Sarana & 12 & 100,00 \\
Pelatihan & 9 & 75,00 \\
Pendampingan & & \\
Kelompok Sasaran & 11 & 100,00 \\
Individu & 11 & 100,00 \\
Kelompok/Lembaga & & \\
Wilayah Sasaran & 10 & 76,92 \\
Kampung/Desa & &
\end{tabular}


Umum

Usia Sasaran

Muda

Tidak ditentukan

Gender

Wanita

Tidak ditentukan

Sektor

Adapun proporsi LAZNAS berdasarkan dimensi yang diteliti yang disajikan sebagaiamana Tabel 7 menunjukkan bahwa dari dimensi jenis bantuan, tidak semua LAZNAS memberikan batuan dalam bentuk pemberian sarana dan pendampingan. Sebanyak 8 dari 12 LAZNAS yang memberikan bantuan sarana, sementara bantuan pendampingan diberikan oleh 9 LAZNAS. Namun dari aspek kelompok sasaran, seluruh LAZNAS memiliki kelompok sasaran baik skala individual mustahik maupun kelompok/lembaga. Sementara dari apek wilayah terdapat 10 LAZNAS yang juga terfokus pada pengembangan usaha pada tingkat desa dan atau kampung dan atau memiliki desa binaan. Namun hanya 3 LAZNAS atau 23,08 persen yang memiliki program pemberdayaan secara langsung terkait dengan generasi muda; dan hanya 1 LAZNAS yang memiliki program utama pemberdayaan ekonomi wanita. Pada sisi lain LAZNAS juga telah mengadaptasi unsur pengembangan pertanian dalam konsep pemberdayaan mustahik, yaitu sebanyak 9 LAZNAS. 
Kinerja Pengelolaan Program Pemberdayaan Mustabik: Kasus BAZNAS dan Rumah Zakat

Organisasi pengelola zakat terbesar di Indonesia dimiliki oleh LAZ pemerintah atau BAZNAS. Kinerja pengumpulan zakat BAZNAS sebagaimana Tabel 8 menunjukkan bahwa jumlah zakat yang dikumpulkan BAZNAS mencapai sekitar 23,7 miliar untuk tahun 2010. Selang lima tahun berikutnya yaitu 2014, jumlah zakat yang terkumpul tiga kali lipat atau sekitar 67 miliar rupiah. Sementara pada tahun yang sama infak dan sedekah yang terkumpul di BAZNAZ sebesar 14,2 miliar rupiah. Jumlah ini setengah dari jumlah infak dan sedekah tahun 2005.

\section{Tabel 8}

Dana Zakat dan Infaq yang Diterima Baznas

\begin{tabular}{crcr}
\hline Tahun & \multicolumn{1}{c}{$\begin{array}{c}\text { Zakat } \\
\text { (juta rupiah) }\end{array}$} & $\begin{array}{c}\text { Infak/Sedekah } \\
\text { (juta rupiah) }\end{array}$ & $\begin{array}{c}\text { Total } \\
\text { (juta rupiah) }\end{array}$ \\
\hline 2005 & $2.540,6$ & $28.784,8$ & $31.325,4$ \\
2006 & $4.825,5$ & $12.455,5$ & $17.281,0$ \\
2007 & $8.303,9$ & $6.017,1$ & $14.321,0$ \\
2008 & $15.355,0$ & $3.288,4$ & $18.643,4$ \\
2009 & 19371,2 & $5.887,8$ & $25.259,0$ \\
2010 & $23.661,0$ & $3.483,3$ & $27.144,3$ \\
2011 & $32.986,9$ & $7.417,0$ & $40.403,9$ \\
2012 & $40.388,0$ & $9.824,5$ & $50.212,5$ \\
2013 & $50.741,7$ & $6.762,8$ & $57.504,5$ \\
2014 & $68.983,1$ & $14.235,5$ & $83.218,6$ \\
\hline
\end{tabular}

Sumber: Laporan Keuangan Baznas Berbagai tahun 
Adapun penyaluran dana oleh BAZNAS untuk program pemberdayaan ekonomi sebagaimana disajikan pada Gambar 7 menunjukkan bahwa proporsi dana program pemberdayaan terhadap total dana yang disalurkan berfluktuasi selama lima tahun terakhir, dengan kecenderungan menurun. Pada tahun 2011 pproporsi program perberdayaan sekitar 17 persen, namun menurun dengan tajam untuk periode 2012, dan pada tahun 2012 berada dibawah 10 persen. Tentunya fluktuasi ini didasarkan pada pertimbangan prioritas yang mendesak bagi BAZNAS untuk kebutuhan mustahik, misalnya: tanggap darurat, kesehatan, dan sosial kemasyarakatan lainnya.

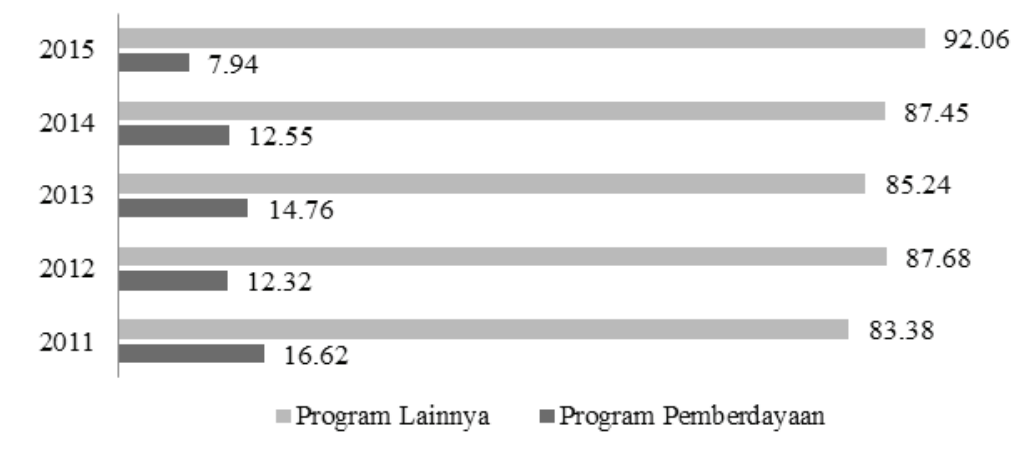

Catatan: Tahun 2011 Belum termasuk Bulan Agustus dan Oktober Sumber: Laporan Keuangan BAZNAS berbagai tahun, diolah

\section{Gambar 7}

\section{Proporsi Program Pemberdayaan BAZNAS Tahun 2011-2015}

Selanjutnya proporsi kedua program pemberdayaan BAZNAS untuk tahun 2015 sebagaimana Gambar 10 menunjukkan bahwa 60 persen program ekonomi diarahkan untuk BQB, sisanya ZCD. Meskipun demikian, proporsi BQB terhadap total dana yang disalurkan BAZNAS hanya sebesar 3 persen (Gambar 11). 


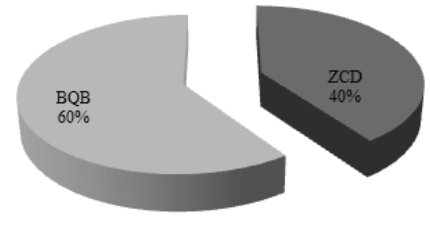

Sumber: Laporan Keuangan

BAZNAS 2015, diolah

\section{Gambar 8}

Proporsi Masing-masing Program Pemberdayaan BAZNAS Tahun 2015



Sumber: Laporan Keuangan BAZNAS 2015, diolah

Gambar 9

Proporsi Program Baitul Qiradh BAZNAS Terhadap Dana Disalurkan Tahun 2015

Pada sisi lain kinerja pengumpulan zakat dan donasi lainnya pada LAZNAS Rumah Zakat sebagaimana Gambar 10 menunjukkan peningkatan signifikan setiap tahunnya, dari 135,08 milyar pada tahun 2010, menjadi 198, 33 milyar pada tahun 2014. Dari jumlah donasi yang terkumpul pada tahun 2014, 20 persen diantaranya disalurkan pada program pemberdayaan ekonomi, 20 persen kesehatan, 26 persen pendidikan, dan 16 persen untuk qurban, dan program lainnya bervariasi antara 1 hingga 4 persen (Gambar 11). 


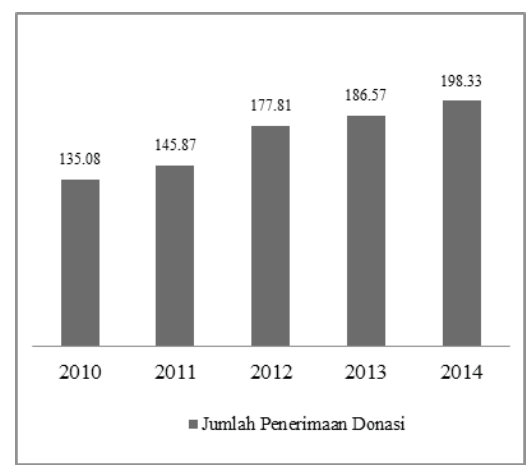

Sumber: Laporan Tahunan Rumah Zakat 2014 hal. 38

Gambar 10

Jumlah Penerimaan Donasi Rumah Zakat dalam Milyar Rupiah Tahun 2014

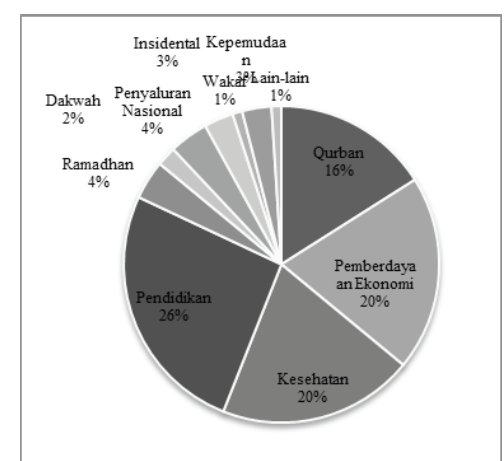

Sumber: Laporan Tahunan Rumah Zakat 2014 hal. 38

Gambar 11

Komposisi Penyaluran Perpos Dana Rumah Zakat Tahun 2014

\section{Tabel 9}

Penerima layanan manfaat Program Rumah Zakat Tahun 2003-2014

\begin{tabular}{ccccccc}
\hline \multirow{7}{*}{ Tahun } & \multicolumn{5}{c}{ Penerima Layanan Manfaat } \\
\cline { 2 - 6 } & $\begin{array}{c}\text { Senyum } \\
\text { Sehat }\end{array}$ & $\begin{array}{c}\text { Senyum } \\
\text { Juara }\end{array}$ & $\begin{array}{c}\text { Senyum } \\
\text { Mandiri }\end{array}$ & $\begin{array}{c}\text { Senyum } \\
\text { Lestari }\end{array}$ & Jumlah & $\begin{array}{c}\text { Pertumbuhan } \\
(\%)\end{array}$ \\
\hline 2003 & 9.129 & 2.506 & 227 & 674 & 12.536 & - \\
2004 & 14.692 & 4.115 & 363 & 702 & 19.872 & 38,52 \\
2005 & 19.100 & 5.715 & 472 & 913 & 26.200 & 38,97 \\
2006 & 24.829 & 9.782 & 613 & 1.186 & 36.410 & 189,99 \\
2008 & 149.033 & 25.101 & 41.112 & 42.613 & 257.859 & 144,22 \\
2009 & 197.089 & 28.095 & 58.745 & 15.821 & 299.750 & 16,25
\end{tabular}




\begin{tabular}{ccccccc}
2010 & 241.172 & 277.004 & 57.698 & 77.755 & 653.629 & 118,06 \\
2011 & 329.281 & 228.859 & 214.409 & 65.931 & 838.480 & 28,28 \\
2012 & 537.875 & 642.009 & 336.107 & 26.356 & 1.542 .347 & 83,95 \\
2013 & 862.945 & 747.076 & 350.575 & 515.096 & 2.475 .692 & 60,51 \\
2014 & 1.112 .193 & 504.456 & 450.868 & 570.680 & 2.638 .197 & 6,56 \\
\hline Total & 3.584 .097 & 2.493 .430 & 1.511 .232 & 1.317 .798 & 8.906 .557 & - \\
\hline
\end{tabular}

Sumber: Laporan Tahunan Rumah Zakat 2014 hal. 46

Adapun mustahik penerima layanan manfaat terbesar pada LAZNAS Rumah Zakat selama kurun waktu 2003-2014 (Tabel 9) telah mencapai 9 juta lebih, dan khusus bidang ekonomi (Senyum Mandiri) sebesar 1,5 juta lebih. Secara total pertumbuhan penerima layanan manfaat mengalami peningkatan setiap tahunnya, pertumbuhan tertinggi dialami pada tahun 2007 sebesar 190 persen. Peningkatan terjadi untuk seluruh jenis program kecuali bidang ekonomi, yang hanya mencapai 43 orang penerima layanan manfaat. Namun pada tahun 2008 penerima layanan manfaat program ekonomi mengalami peningkatan signifikan, yang selanjutnya juga dialami pada tahun 2009 hingga 2014, dengan jumlah penerima latanan manfaat 450.868 orang, yang dirinci ke dalam beberapa program ekonomi sebagaimana Tabel 10 .

\section{Tabel 10}

Penerima Layanan Manfaat LAZ Rumah Zakat Program Ekonomi Tahun 2014

\begin{tabular}{llll}
\hline \multicolumn{1}{c}{ Nama Program } & & \multicolumn{1}{c}{ Jumlah } & \multicolumn{1}{c}{$\begin{array}{c}\text { Persentase } \\
(\%)\end{array}$} \\
\hline Bantuan Wirausaha & orang & 90.724 & 20,12 \\
Gaduh Sapi dan Domba & orang & 2.480 & 0,55 \\
Pembinaan Masyarakat & orang & 311.768 & 69,15 \\
Bantuan Ekonomi Lainnya & orang & 45.896 & 10,18 \\
\hline Total & orang & 450.868 & 100,00 \\
\hline
\end{tabular}

Sumber: Laporan Tahunan Rumah Zakat 2014, diolah 
Tabel 10 menunjukkan bahwa penerima layanan manfaat terbesar program ekonomi yaitu pembinaan masyarakat yang mencapai 311.768 orang atau 69,15 persen. Posisi selanjutnya yaitu bantuan wirausaha sebesar 20,12 persen atau sebanyak 90.724 mustahik. Adapun bentuk bantuan wirausaha terdiri dari 8 jenis bantuan, yaitu: pelatihan keterampilan, pemberian sarana usaha, pemberian modal, pendampingan bisnis, pendampingan GMP, penguatan produk, legalitas dan penguatan jaringan. Proporsi penerima layanan manfaat terbesar bantuan wirausaha sebagaimana Tabel 11 yaitu pendampingan bisnis yang mencapai lebih dari separuh penerima manfaat bantuan wirausaha. Posisi kedua yaitu pendampingan GMP sekitar 17 persen. Adapun penyaluran dana dalam bentuk legalitas usaha dan sarana memiliki proporsi yang tidak mencapai 1 persen.

\section{Tabel 11}

\section{Distribusi Penerima Layanan Manfaat Bantuan Wirausaha Rumah Zakat Tahun 2014}

\begin{tabular}{llll}
\hline No & \multicolumn{1}{c}{ Jenis Bantuan } & \multicolumn{1}{c}{$\begin{array}{c}\text { Penerima } \\
\text { (orang) }\end{array}$} & $\begin{array}{c}\text { Manfaat } \\
(\%)\end{array}$ \\
\hline 1 & Pelatihan Keterampilan & 5.633 & 6,21 \\
2 & Sarana Usaha & 544 & 0,60 \\
3 & Pemberian Modal & 2.162 & 2,38 \\
4 & Pendampingan Bisnis & 60.592 & 66,79 \\
5 & Pendampingan GMP & 15.180 & 16,73 \\
6 & Penguatan produk & 3.338 & 3,68 \\
7 & Legalitas Usaha & 858 & 0,95 \\
8 & Penguatan jaringan & 2.417 & 2,66 \\
\hline
\end{tabular}

Sumber: Laporan Tahunan Rumah Zakat 2014, diolah

\section{Kesimpulan}

Bentuk program pemberdayaan yang dilakukan oleh LAZNAS di 
Indonesia terdiri dari: bantuan modal, bantuan sarana, pelatihan dan pendampingan, serta lainnya seperti penguatan produk, legalitas usaha dan penguatan jaringan. Namun tidak seluruh LAZNAS mengadopsi jenis bantuan tersebut. Selanjutnya seluruh LAZNAS memiliki target pemberdayaan baik mustahik perorangan maupun kelompok. LAZNAS juga secara umum memiliki desa binaan, sehingga memfokuskan program berbasis wilayah desa/kampung. Pada sisi lain, LAZNAS secara umum telah memberi ruang bagi berkembangnya usaha masyarakat pada sektor pertanian secara umum. Namun masih minim memberikan perhatian pada mustahik usia muda dan perempuan.

\section{Daftar Pustaka}

Ali, Mohammad Daud. 1988. Sistem Ekonomi Islam Zakat dan Wakaf, Jakarta: UI Press

BMM. (tanpa tahun). Program. Tersedia pada: www. baitulmaalmuamalat.org/

Bangun Sejahtera Mitra Umat. (tanpa tahun). Program. Tersedia pada: http://www.laznasbsm.or.id/ .

BAZNAS. (tanpa tahun). Program. Tersedia pada: http://pusat. baznas.go.id/

Bariadi, Lili et. al., 2005. Zakat dan Wirausaha . Jakarta: CED

Baznas. 2014. Laporan Auditor Independen atas Laporan Keuangan Baznas Tahun 2013 dan 2012. Tersedia pada: http://pusat. baznas.go.id

Baznas. 2012. Laporan Auditor Independen atas Laporan Keuangan Baznas Tahun 2011 dan 2010. Tersedia pada: http://baznas. or.id

Baznas. 2010. Laporan Auditor Independen atas Laporan Keuangan Baznas Tahun 2009 dan 2008. Tersedia pada: http://pusat. baznas.go.id

Baznas. 2008. Laporan Auditor Independen atas Laporan Keuangan Baznas Tahun 2007 dan 2006. Tersedia pada: http://pusat. baznas.go.id

Baznas. 2007. Laporan Auditor Independen atas Laporan Keuangan Baznas Tahun 2006 dan 2005. Tersedia pada: http://pusat. 
baznas.go.id

Baznas. 2005. Laporan Auditor Independen atas Laporan Keuangan Baznas Tahun 2004. Tersedia pada: http://pusat.baznas.go.id BMH. (tanpa tahun). Program. Tersedia pada: http://www.bmh. or.id

Dompet Duafa. (tanpa tahun). Program. Tersedia pada: http://www. dompetdhuafa.org

Dompet Peduli Ummat Daruttauhid. (tanpa tahun). Program. Tersedia pada: http://www.dpu-daaruttaubiid.org

Febianto, Irawan dan Ashany Arimbi Mardillaa. 2012. "The Impact of Qardhul Hasan Financing Using Zakah Funds on Economic Empowerment (Case Study of Dompet Dhuafa, West Java, Indonesia)". Asian Business Review, Vol. 1, No: 15-20

Firdaus, dkk, 2012. Economic Estimation and Determinations of Zakat Potential in Indonesia. IRTI Working paper Series. Tersedia pada: http://irti.org/English/Research/ Documents/334.pdf

Ibrahim, Patmawati and Ghazali, Ruzia. 2014. "Zakah As an Islamic Micro-Financing Mechanism to Productive Zakah Recipients". Asian Economic and Financial Review. Vol. 4, No 1:117-125

Juwaini, Ahmad. 2011. Strategi Pengembangan SDM Zakat Indonesia, dalam Strategi Pengelolaan Zakat di Indonesia. Jakarta: FOZ

Kahf, M. 1997. "Potential Effects of Zakat on Government Budget". IIUM Journal of Economics and Management. Vol.5, No.1: 6785

LAZ Dewan Da'wah Islamiyah Indonesia. (tanpa tahun). Program. Tersedia pada: http://www. lazisdewandakwahpusat.org LAZISMU. (tanpa tahun). Program. Tersedia pada: http://www. lazismu.org

LAZISNU. (tanpa tahun). Program. Tersedia pada: http://www. lazisnu.or.id

Nafiah, Lailiyatun. 2015. "Pengaruh Pendayagunaan Zakat Produktif terhadap Kesejahteraan Mustahik Pada Program Ternak Bergulir Baznas Kabupaten Gresik." El-Qist. Vol. 5, No 1: 307- 321

Noerwenda, F. and Mulyaningsih, H.D. 2014. "New Challenges in Creating Social Entrepreneurs Based on Sharia". IPEDR. Vol 73, No 3: 10-13 
Qadir, Abduracchman . 2001. Zakat Dalam Dimensi Mahdah dan Sosial. Cet. 2. Jakarta: PT. Raja Grafindo Persada

Peraturan Direktur Jenderal Pajak Nomor PER-33/PJ/2011 Tentang Badan/Lembaga Yang Dibentuk atau Disahkan oleh Pemerintah yang Ditetapkan Sebagai Penerima Zakat atau Sumbangan Keagamaan yang Sifatnya Wajib yang Dapat Dikurangkan dari Penghasilan Bruto

Peraturan Menteri Agama No 52 tahun 2014 Tentang Syarat dan Tata Cara Perhitungan Zakat Mal dan Zakat Fitrah Serta Pendayagunaan Zakat untuk Usaha Pproduktif

PKPU. (tanpa tahun). Program. Tersedia pada: http://www.pkpu. org

PZU. (tanpa tahun). Program. Tersedia pada: http://www.pzu.or.id Ra'ana, Irfan Mahmud. 1979. Economics System Under The Great (Sistem Ekonomi Pemerintahan Umar Ibn Khathab), terj. Mansuruddin Djoely. Jakarta: Pustaka Firdaus

Ridwan Mas'ud, Muhammad. 2005. Zakat dan Kemiskinan Instrumen Pemberdayaan Ekonomi Umat. Yogyakarta: UII Press

Rumah Zakat. 2014. Laporan Tahunan Rumah Zakat Tahun 2014. Penerbit: Rumah Zakat . (tanpa tahun). Program. Tersedia pada: http://www. rumahzakat.org

Suharto, Edi. 2005. Membangun Masyarakat Memberdayakan Rakyat, Kajian Strategi Pembangunan Kesejahteraan Sosial \& Pekerjaan Sosial, Bandung: PT Refika Aditama

Triwibowo, Darwan dan Subono, Nur Iman. 2009. Meretas Arah Kebijakan Sosial Baru di Indonesia. Jakarta: Pustaka LP3ES Undang-Undang Nomor 23 tahun 2011 Tentang Pengelolaan Zakat Yasin, Ahmad Hadi. 2011. Panduan Zakat. Dompet Dhuafa Republika: Jakarta

Yayasan Dana Sosial Al Falah. Program. Tersedia pada: http://www. ydsf.org 